\title{
GIOVANNI ARRIGHI IN BEIJING
}

\author{
Ganesh Trichur \\ Political Economy \\ Bates College \\ gtrichur@bates.edu
}

\section{Steven Sherman \\ PhD, Binghamton Sociology, 1999 \\ threehegemons@hotmail.com}

Giovanni Arrighi's Adam Smith in Beijing (ASB) subverts the temporality and conceptual vocabulary employed by most writers working in a Marxist tradition. In this view, capitalism is a mode of production which eventually encompasses the entire world. Perhaps it began in England and expanded from there. Perhaps its expansion through colonial empires should be seen as part of its constitution, rather than an after effect (i.e. the perspective of Wallerstein). In any case, it eventually dominates the world and every place that is a part of it through such phenomena as, multinational corporations, wage labor, and international capital flows. The particular class relations, political systems, and international relations that held before the spread of capitalism are only of interest to the extent that they leave a residue which may be reclaimed by actors seeking to reinforce or undermine the rule of capital in particular places. For Arrighi, Chinese development neither is, nor ever was, simply "capitalist." Rather, it was, and continues to be "Smithian," devoted to the maintenance and expansion of a market society (the obvious irony here is that China is seen as more "Smithian" than those places which most heartily celebrate the Scottish political economist). It is constituted through "accumulation without dispossession," rather than the opposite process dominant in the West and its subordinate territories. In some ways, Arrighi's perspective parallels that of right wing theorists of world history (Spengler, Toynbee, or more recently John Gray) who emphasize a difference between the West and other major centers of civilization. However, they typically posit this difference to lie in deep seated patterns of thought that distinguish the West from the rest. Arrighi shares the belief that civilizations (or social structures) may differ across the long duree of world history; however, for him, the difference is grounded in the material basis of political rule, rather than culture. And the difference is consequential for understanding the trajectory of global capitalism. Ironically, in the current moment, when the triumph of capitalism has been loudly trumpeted, a non-capitalist market system is poised to play a larger role in reshaping the global ecumene than it has for at least three hundred years.

There are both political and intellectual implications to this analysis, although Arrighi does not make them explicit. Politically, it suggests that there are no material grounds for the global solidarity of a "multitude" writhing under the lash of a homogeneous and total Empire. Activists and theorists may need to better understand the long term social structures they are embedded in. This advice fits rather well with the global political dynamics of the last decade, when a number of countries -- not only China, but also Russia and Iran, at least -- fail to fall neatly on the right/left continuum. The direction pointed to in ASB suggests that there may be 
real differences in the effort to reform a market society as opposed to a capitalist one. The other political implication of ASB is the historical role of the global South in bringing an end to Western domination. This political emergence of the global South forms the context for the peaceful and inclusive economic expansion of China (and of India) since the late 20th century. Intellectually, it suggests a broad project for reformulating world history. ASB is focused on the long term difference between the structure and trajectory of Western Europe vs. China. However, does this not open the potential for differentially understanding a number of regions? There are strong civilizational differences between Western industrial-capitalist societies and market societies. It may not be the case that there are other non-capitalist market societies. But perhaps other empires or historical formations have oriented regions in ways that are not simply erased with the arrival of capitalism, and might emerge as resources as they try to formulate a place for themselves in a world where the power of the West has begun to decline. These civilizational differences suggest that unlike earlier hegemonic transitions, the ascent of East Asian market societies may not ensue in world wars or in a "clash of civilizations" that destroyed the foundations of earlier world orders. The Epilogue to ASB cites approvingly the words of A. Giridharadas on the implications of the rise of China and India for the global status quo: "What it clearly means already is that the day when a cozy club of the rich - the United States, the strongest economies of Western Europe and Japan - sets the pace for the rest of the world, passing out instructions and assigning grades, is fast drawing to a close." Arrighi welcomes this as an accurate observation, "but on condition that the ruling groups of the global South in general, and of China and India in particular, open up a path capable of emancipating not just their states but the entire world from the social and ecological devastations entailed in Western capitalist development.”

In this essay we elaborate upon two strands in Arrighi's impressive architecture. The first is the legacy of Marx - best represented in the engagements with Robert Brenner (Part II of ASB) and David Harvey (Part III of ASB). The outcome is a novel interpretation of the renaissance of East Asia and the peaceful rise of China in the world system. The second is the legacy of Adam Smith for understanding the relationship between East Asian traditions and a world market society in formation.

\section{SPATIO-TEMPORALITY OF GLOBAL TURBULENCE}

In a debate with Frank, Brenner argues that the formation of the world market in itself is insufficient to promote capitalist development in the absence of two necessary conditions. First, the organizers of production (capitalists) must have lost the capacity to reproduce themselves and their established class position outside the market economy. Second, the direct producers must have lost control over the means of production. Arrighi claims that insofar as the second condition is necessary for capitalist development, it is possible to maintain that the spread of a market economy in China through the pursuit of profit that is not necessarily capitalist.

Brenner also attempted to track and explain the current system-wide turbulence using "uneven economic development" - the name for a process of inter-capitalist competition whereby laggards in capitalist development (Germany and Japan) try to catch up, and eventually succeed in catching up, with the leader (the US) - to explain both the long post-war boom of the 1950s and 1960s, and the crisis of profitability (1965-1973) that brought the boom to an end. The failure 


\section{JOURNAL OF WORLD-SYSTEMS RESEARCH}

of core governments and core capitalist enterprises to eliminate excess capacity "spatially generalized and temporally extended" the squeeze on profits between 1973 and 1993. Brenner’s focus is on the performance of manufacturing industries in the US, Germany, and Japan, and on the ways in which the US manipulated currency exchange rates to restore manufacturing competitiveness. Arrighi points out that Brenner's analysis excludes from consideration most of the global South despite its rising share in world manufacturing output and strong North-South convergence in the degree of industrialization, without any corresponding income convergence.

Arrighi's engagement with the current global turbulence is through a vastly larger spatiotemporal canvas that compares and contrasts an earlier 19th century cycle of expansion (18481873) and downturn (1873-1896) with the 20th century cycle of expansion (1953-1973) and contraction (1973-1993). Not only were all the features of "uneven economic development" present in both long cycles; in each downturn, temporary financial expansions (the Edwardian belle époque of 1896-1914 resembling in important ways the US economic upturn and great euphoria of the 1990s) restored profitability. Arrighi argues that these temporary upturns represent historically recurring systemic tendencies towards "financialization" and intensification of inter-capitalist competition. The early 20th century economic upturn ended in global economic collapse and two world wars; and yet these outcomes appear to have been exceptional (not the "standard" capitalist method of restoring profitability as Brenner claims). The differences between the two downturns are more compelling. At the very outset of the late 20th century inflationary downturn the gold-dollar standard broke down followed by extensive US use of currency devaluations and revaluations - in contrast during the 1873-96 deflationary downturn core governments continued using the metallic standard and did not manipulate exchange rates. In the late 20th century downturn core states promoted greater integration of the world market with the leading US state concentrating world military capabilities and absorbing world liquidity at unprecedented rates - in contrast, in the late $19^{\text {th }}$ century core states actively pursued protectionist practices and overseas colonial empires, and escalated the arms race, all of which ended in a world market crisis, although the leading British state continued its overseas investment and poured money capital into the US.

Historical capitalism over the longue duree provides no evidence for Brenner's identification of capitalism with industrial capitalism. Despite Brenner's Marxist legacy, Arrighi identifies two other major problems: neither labor-capital conflicts nor geopolitics appear to have any importance for Brenner even though in both downturns their roles are hard to ignore. European class struggles interacted with inter-capitalist competition to contribute to the explosive growth of British overseas investments (in the 1880s and 1900s) and export of capital; they contributed to the "politicization" of inter-capitalist competition through aggressive overseas empire-building, interstate rivalries and wars, that were instrumental in both the temporary revival of profits (18901914) and the eventual breakdown of the UK-centered global market. Escalating labor militancy in the core and advancing communist revolution in the peripheries actively shaped the social parameters of the "labor-friendly" postwar hegemonic US world order which created the institutional conditions for the Golden Age of capitalism in the 1950s and 1960s. The end of the Golden Age, Arrighi argues, was the economic cost of uneven economic development consciously and actively encouraged "from above" by a globalizing warfare-welfare US state driven by social and political objectives: the containment of Communism, the taming of nationalism, and the consolidation of US hegemony through active upgrading of productive apparatuses of US protectorates and promotion of full employment and high mass consumption in 
the West. But the US warfare-welfare state failed to attain its social and political objectives in the global South: promoting Third World development; containing communism and nationalism. US military defeat in Vietnam was the "signal crisis" of US hegemony: it was constitutive of all the symptoms of 20th century global economic turbulence documented in Brenner. This signal crisis deepened in the course of the 1979 Iranian Revolution, the second hike in OPEC-oil prices, and the Soviet invasion of Afghanistan. Until the US switch to ultra-tight monetary policy in 1979-80, US policies tended to repel the growing mass of private capital accumulating in extraterritorial financial markets. Brenner ignores the Euro-currency markets that accumulated dollar deposits from US banks and MNCs. Currency speculators used these deposits to bet against the stability of the US-controlled fixed exchange rate system. Arrighi seems to forget the role played by the PRC and the USSR in the creation of Euro-dollar money markets in London and Paris. Devaluation of the dollar and the 1971 withdrawal from the gold standard became the US means of freeing itself from monetary constraints on its struggle for dominance in the Third World. But this struggle only worsened inflationary pressures in the core until the Reagan-Thatcher monetarist counterrevolution of 1979-80 shifted US state action from the supply side to the demand side of the financial expansion, re-routing global capital flows towards the US and the dollar. As the leading agency sustaining the financial expansion and deindustrialization, US power and prestige were temporarily restored through the debt crisis and collapse of the Third World in the 1980s; and through the bankruptcy and disintegration of the USSR in the course of renewed escalation of the arms race. However, this restoration of US power also made the US the world's greatest debtor nation, dependent foremost on East Asian states for financing its debts, deficits, and warmaking. The second Gulf War however revealed again the limits of US war-making: "in all likelihood US difficulties in Iraq will, in retrospect, be seen as having precipitated its terminal crisis."

\section{CAPITALISTIC IMPERIALISM AND SPATIAL FIXES OVER THE LONGUE DUREE}

Nevertheless, the US remains the world's greatest military power. Arrighi evaluates the world historical trajectory of "capitalist imperialism" - a contradictory fusion of "the politics of state and empire" and "the molecular processes of capital accumulation in space and time" within individual capitalist states (Harvey) - to see to what extent the US can continue to deploy its "residual" military power to resist decline. Harvey argues that the production of new territorially enlarged spaces endowed with necessary physical and social infrastructures can become a "spatial fix" to over-accumulated capital even though such a "switch" of capital flows will encounter resistance. For instance, the PRC may well be the new geographical space with the capacity to absorb capital surpluses but the US will resist such a rerouting of capital flows not only because it enhances the competitive position of the PRC; it threatens internal stability within the US. One way out of this impasse is "accumulation by dispossession" - the use of financial means, crises of devaluation, to rid the system of overaccumulation.

Arrighi draws upon Marx's observations to argue that across the entire space-time of historical capitalism, finance capital and state institutions were linked by national debts and the international credit system in an invisible "inter-capitalist cooperation" - involving financial transfers from the incumbent center of accumulation to the newly emerging center - which "restarted" the accumulation process over and over again in newer and larger territorial containers of 


\section{JOURNAL OF WORLD-SYSTEMS RESEARCH}

wealth and power. The sequence of national debts and the mechanism of the international credit system observed by Marx that produces a debtor-creditor relation between incumbent center and emerging center is a world historical sequence of spatial fixes of increasing scale and scope. Wars involving the incumbent center and the financing of those wars by the emerging center eventually reversed the debtor-creditor relation. It also reduced the need for accumulation by dispossession in the newly emerging center. However, compared to earlier hegemonic transitions, the fact that the US has been borrowing enormous amounts of capital from the newly emerging center of accumulation in East Asia appears as an historical anomaly. Arrighi asks whether this anomaly is because the process of accumulation by dispossession has reached its limits - either because the leading emergent center (China) is accumulating capital by other means or because coercive means by the incumbent center (US) can no longer create a spatial fix adequate to the overaccumulation

crisis.

Arrighi also argues that the most crucial and recurring form of accumulation by dispossession has been the use of military force by Western states - capitalism, industrialism, and militarism synergized in the West - to provide the endless accumulation of capital and power with spatial fixes of increasing scale and scope. "Capitalist imperialism" is really the name for the effects of the long-term "extroversion" of the European developmental path that made successful pursuit of profits and power within the Western interstate system depend critically on long-distance trade and plunder of non-Western spaces. Extroversion of the struggle for power also ensured that interstate competition for mobile capital would empower the capitalist organizations that controlled those financial resources; and that this interstate competition would be continually renewed by the need of territorial organizations to outdo one another in gaining privileged access to non-Western resources. In the political exchange that framed the first Genoese-Iberian systemic cycle of accumulation, Genoese capitalism and Iberian imperialism retained their separate organizational identities from the beginning to the end of the cycle. In the second Dutch systemic cycle of accumulation, there was a far greater interpenetration of capitalism and imperialism through partial internalization of protection costs (costs of war-making). A complete fusion of capitalism and imperialism in the British systemic cycle of accumulation emerged only because Britain's ability to dominate the continental balance of military power synergized with British imperial control over India's demographic and financial resources. The greater scale and scope of the British spatial fix however resulted in a far more massive over-accumulation of capital for which only a continent-sized island of the US-type could supply an adequate spatial fix. Arrighi argues that FDR's political vision of "world government" was a conscious projection on a world scale of the domestic New Deal. If FDR's vision appeared too idealistic to business and government, a downsized, militarized world-government project led by Truman proved realistic in circumstances created by the Korean War. An artfully inflated Communist threat helped project the image of the US as a "legitimate protector" of Western European interests and the leader of the golden age of capitalist expansion in the 1950s and 1960s. US defeat in Vietnam however, created a legitimacy crisis. Like the earlier $19^{\text {th }}$ century golden age (1848-1875) the golden age of the $20^{\text {th }}$ century (1953-1973) ended in a long period of financial expansion and resurgent imperialism. What was distinctive about the new imperialism (the US invasion of Iraq) was the attempt by the declining hegemonic power to resist decline by attempting to transform itself into a world state. By 2004 this project had become a "quagmire," adding to the widespread global perception that the US in the guise of offering protection was really running a protection racket. "Just as the US emerged as the real winner of the Second World War after the USSR had 
broken the back of the Wehrmacht in 1942-43, so now all the evidence points to China as the real winner of the war on terror." But has the failure of the US imperial project also created the conditions for China to pioneer peacefully the social and economic empowerment of peoples of the global South?

\section{PERSISTENCE OF THE SMITHIAN LEGACY}

The rise of China as the fastest growing economy in the world has provoked responses from US foreign policy analysts and from Marxist scholars that seem to misread the nature of China's economic ascent and its economic reforms. US foreign policy analysts like Kaplan and Mearsheimer argue that the economic ascent of China will translate into formidable military power that the US should contain through a newer system of alliances. This fetishism of competitive military relations between great powers ignores historical instances of cooperative relations between incumbent and emerging great powers: following a long period of mutual hostility Britain (incumbent power) and the US (emerging power) cemented strong cooperative relations over the course of the $20^{\text {th }}$ century. Why should "realism" rule out closer cooperation between China (emerging great power) and the US (incumbent great power) as an equally likely future outcome? China's foreign policy strategy in fact resembles the strategy followed by the emerging power (US) vis-à-vis the incumbent power (Britain) in the early 20th century. China is letting the US exhaust itself militarily and financially in an endless war on terror while enriching itself by supplying goods and credit to the US. It is also using its vast domestic market to win over allies in the creation of a new PRC-centered new world order. Why should realists rule out of consideration the possibility that a PRC-centered East Asian world economy will follow the peaceful traditions of an earlier Sino-centric East Asian world economy? While there are strong civilizational differences between China and the West, there are no historical reasons to assume that these civilizational differences will translate into a Huntington-style "clash of civilizations." Foremost among these differences at the political level is the near-absence in East Asia of the kind of interstate military competition endemic to the Western developmental path - Polanyi's "hundred years of peace" (1815-1914) within Europe co-existed with active European pursuit of overseas empires elsewhere. Insofar as interstate competition in East Asia (in particular between China and Japan) did occur, it only drove the region's developmental path towards state-making and national economy-making. Qing territorial expansion between 1644 and 1760s was a "defensive" strategy adopted against persistent Mongol raids; and late-Imperial China became the center of concentrated regional power in contrast to most of European history where there was no such "center" or regional peace. In fact, Arrighi observes in East Asia three centuries of intraregional peace (or five hundred years, 1392-1894, as far as China is concerned), as well as the absence of any tendency to build overseas empires. Why should this historical legacy of a peaceful East Asian interstate system not inform US foreign policy vis-à-vis China in the new millennium?

These civilizational differences at the political level, Arrighi argues, correspond to civilizational differences at the economic level. Ming and Qing successes in developing the largest Smithian market economy in the world lie behind the "introversion" of the power struggles in East Asia. Although both Western Europe (1350-1650) and Ming China (1368-1644) reached high-level equilibrium traps of Smithian market-based development, Smith's "natural" 


\section{JOURNAL OF WORLD-SYSTEMS RESEARCH}

path - in which a country progresses from agriculture to industry to foreign trade, and mobilizes human rather than non-human resources in pursuing economic improvement - persisted in East Asia from the 16th to the 18th centuries. The Ming and early Qing creation of a vast agricultural economy proceeded alongside the creation of the world's largest domestic market. An extensive intra-regional commerce was regulated effectively to keep a vibrant East Asian capitalism (whose main bearer was overseas Chinese merchant capitalists) confined to the outer rim of the systems' states. Defeat and demilitarization of Chinese merchant capitalists in 1683 cleared the way for an "Industrious Revolution" that unfolded within the limits of labor-absorbing institutions centered on the household, family, and village community. The "invisible hand" of dynastic governments forced capitalists to compete with one another in the general social interest and promoted an $18^{\text {th }}$ century "Chinese economic miracle.” By contrast, the sequence of larger and larger states that led the Western developmental path followed Smith's "unnatural" path in which capitalists exercised greater power to impose their class interest at the expense of the general social interest: "conversely, the absence of anything comparable to such a sequence in East Asia can be taken as the clearest sign that, prior to the Great Divergence, the East Asian developmental path was as market-based as the European but was not the bearer of a capitalist dynamic." These fundamental divergences between the Eastern and Western developmental paths also created the conditions for their relational intertwining in which Western militarism incorporated, without transforming the East Asian developmental path into the Western developmental path - first under British and then under US capitalistic imperialism.

The Smithian legacies of the East Asian tradition have combined in the 1980s and 1990s with the legacies of the Chinese peasant Revolution to lead the current phase of regional economic resurgence. Arrighi does not give adequate importance to the role of farmers as agents in China's economic ascent - peasant grassroots initiatives were central in the formation of the post-1978 household responsibility system (Kate Zhou 1996: How the Farmers Changed China) - and he places an emphasis on the symbiosis between the Chinese Party-State and overseas Chinese capitalist diaspora that has been the subject of much critical commentary (Aihwa Ong 2006: Neoliberalism as Exception). He is nevertheless, correct in maintaining that the Chinese state is not a capitalist state in Marx's sense - the PRC-party-state remains in control of its relationship with the capitalist overseas diaspora and the CCP has forced all kinds of capitalists to compete with one another. "The result has been a constant over-accumulation of capital and downward pressure on rates of profits." The contradictions underlying Deng's reforms did facilitate a lot of bureaucratic corruption at the level of decentralized local governments; as well as a crisis of landlessness. The result has been large-scale social unrest, itself part of a long Chinese tradition which undermined Ming dynastic rule. Such corruption does not however mean that China has taken a neoliberal turn nor that it exemplifies a process of "accumulation by dispossession" (Harvey). Neither does it imply that Chinese ruling groups are oblivious to either the history of peasant rebellions or to the present form of rural and urban social unrest.

Perhaps a more important question is how these contradictions and limits may be overcome in the future in such a way that market-based development in the PRC remains embedded in social relations. Much of the data of the last two decades has been discouraging. Since the mid1980s the Gini Coefficient of inequality for China spiked sharply and consistently upward from 0.35 in 1990 to 0.46 in 2002, making China significantly more unequal than most Asian nations. Growing social unrest and the restraint on the growth of the domestic market are two important effects of material inequalities. The hukou system, with its urban bias, remains in place. Insofar as 
the future of East Asian integration depends significantly on the growth of intra-regional markets so as to fully overcome the region's dependence on Northern markets - rendered even more important in the light of the stagnation of the Eurozone and the staggering indebtedness of the US economy - growing inequalities within China and among states in the region limit the potential of Chinese markets to support and reinforce regional growth and expansion. Can China become something more than a poor peoples' welfare state?

In the last few years, a countertrend has emerged, epitomized in the rise of Hu Jintao. New labor laws have been announced and initiatives to develop rural areas have been funded. Most recently, China has announced a large scale stimulus to combat the global recession. "The country is using its nearly $\$ 600$ billion economic stimulus package to make its companies better able to compete in markets at home and abroad, to retrain migrant workers on an immense scale, and to rapidly expand subsidies for research and development" (Keith Bradsher in New York Times, 16 March 2009). From Arrighi's long term perspective, one might argue that long term civilizational tendencies towards self-protection and accumulation without dispossession have persisted to offset the sorts of tendencies noted by Harvey and others. On a global scale, China has also moved in its long term path of the peaceful production of a global market. One can point to several aspects -- it has largely relied on contracts with existing leaders in developing countries, rather than trying to train a cadre of pro-Chinese ideologues and use coups to place them in palaces as it deepens economic relations around the world. It has worked in a low key, non-confrontational manner as it seeks additional space from the looming catastrophe of an excessively indebted US. Finally, we should also note the presence worldwide of small shopkeepers of Chinese descent, in practically every major city. Nestled in poor neighborhoods, without the defensive structures of global NGOs or multinational corporations on their side, they might be seen as the informal ambassadors of the market society. It is impossible to predict the future and confidently state the triumph of one political force or project over another. But Arrighi's long term analysis does convince us that the civilizational structure of the Chinese market society will be one key factor in the reshaping of the global polity in this century. 